\title{
EFFECT OF EXPOSURE OF BACTERIA TO ENDOTOXIN ON THEIR SUSCEPTIBILITY TO THE LETHAL ACTION OF NORMAL SERUM
}

\author{
J. GABRIEL MICHAEL AND MAURICE LANDY \\ Laboratory of Chemical Pharmacology, National Cancer Institute, Bethesda, Maryland
}

Received for publication March 10, 1961

\begin{abstract}
Michael, J. Gabriel (National Cancer Institute, Bethesda, Md.), and Maurice Landy. Effect of exposure of bacteria to endotoxin on their susceptibility to the lethal action of normal serum. J. Bacteriol. 82:257-264. 1961.-The uptake of typhoid endotoxin by Escherichia coli and Shigella dysenteriae was investigated with respect to its effect on the susceptibility of these strains to the bactericidal action of serum. The attachment of endotoxin to the organisms was found to be dependent on time, temperature, concentration, and the physiological state of the bacteria. Short exposure leading to the adsorption or incorporation of small amounts of endotoxin enhanced the lethal effect of serum, whereas long periods of exposure leading to the uptake of larger amounts rendered the bacteria relatively resistant.
\end{abstract}

The somatic antigen ${ }^{1}$ of gram-negative bacteria plays an essential role in the initiation of the serum bactericidal reaction, inasmuch as exposure of bacteria to antibody specific for this somatic complex, in the presence of complement, results in their death. It seemed, therefore, that alteration in the amount or disposition of this complex on the bacterial surface would have important consequences in the bactericidal system.

We have recently reported (Michael and Landy, 1961) that the susceptibility of antigenically related strains of gram-negative bacteria varied inversely to their endotoxin content. It, therefore, seemed reasonable to examine whether fixation of additional endotoxin on bacteria would alter their sensitivity to serum.

\footnotetext{
${ }^{1}$ In this report the designation endotoxin, somatic antigen, and lipopolysaccharide are employed interchangeably for convenience in referring to the surface complexes of gram-negative bacteria which are responsible for the char acteristic antigenic and toxic attributes of these organisms.
}

It is now well established that bacterial antigens can adhere to the surface of cells (De Gregorio, 1955; Davies et al., 1958) such as erythrocytes, leucocytes, liver cells, etc. But descriptions of this adherence phenomenon have been concerned primarily with the newly acquired immunological reactivity of the coated cells, and there have been few indications that this treatment may have additional consequences. The present work shows that the attachment of somatic endotoxic complexes to viable Escherichia coli and Shigella dysenteriae results in significant alterations in their susceptibility to normal and immune serum.

\section{MATERIALS AND METHODS}

Endotoxins. The somatic lipopolysaccharides utilized for sensitization of bacteria had been isolated either by the Boivin or the Westphal methods. They were prepared for coating cells by heating at $100 \mathrm{C}$ for $1 \mathrm{hr}$ or by incubation overnight with $0.02 \mathrm{~N} \mathrm{NaOH}$ prior to use. Crude endotoxin extracts were obtained by boiling heavy bacterial suspensions in saline for $1 \mathrm{hr}$.

Bacteria. E. coli strain, type 0127:B8, was obtained from A. Abrams, Walter Reed Army Institute of Research. S. dysenteriae (Shiga) no. 677 originated from a culture supplied by R. Wedgewood, Western Reserve University. Both strains were colonially homogeneous with regard to their susceptibility to bactericidal action of normal serum.

Bacteria were grown on tryptose agar for 18 hr at $37 \mathrm{C}$. In experiments where cells grown in the $\log$ phase were required, an inoculum of an 18-hr culture was transferred into tryptose broth and incubated at $37 \mathrm{C}$ for $4 \mathrm{hr}$ with constant shaking. For uptake by bacteria, endotoxin was added to tryptose broth in a concentration of 1 mg per ml of medium.

Agglutination tests. The washed bacterial suspension, $0.5 \mathrm{ml}\left(1 \times 10^{9}\right.$ cells per $\left.\mathrm{ml}\right)$, was 
TABLE 1. Adsorption of typhoid somatic antigen on viable Escherichia coli; enhancement of uptake by prior treatment of the endotoxin

\begin{tabular}{|c|c|c|c|c|c|c|c|c|}
\hline \multicolumn{2}{|c|}{ Modification of $E$. coli for agglutination tests } & \multicolumn{7}{|c|}{ Serological reactivity of endotoxin-treated $E$. coli } \\
\hline \multirow{2}{*}{$\begin{array}{l}\text { Prior treatment of } \\
\text { Salmonella typhosa } \\
\text { endotoxin }\end{array}$} & \multirow{2}{*}{$\begin{array}{c}\text { Interaction of } E \text {. coli } \\
\text { and typhoid endotoxin } \\
\text { preparations }\end{array}$} & \multicolumn{7}{|c|}{ Agglutination titers (reciprocals) with $S$. typhosa antiserum* } \\
\hline & & 10 & 20 & 40 & 80 & 160 & 320 & 640 \\
\hline $100 \mathrm{C}$ for $1 \mathrm{hr}$ & Incubated at $37 \mathrm{C}$ & + & + & + & + & + & + & - \\
\hline $\begin{array}{l}0.02 \mathrm{~N} \mathrm{NaOH}, 37 \mathrm{C} \text {, } \\
18 \mathrm{hr}\end{array}$ & $\begin{array}{l}\text { for } 18 \mathrm{hr} ; \\
\text { washed } 3 \text { times }\end{array}$ & + & + & + & + & + & + & - \\
\hline None & with saline & + & + & - & - & - & - & - \\
\hline \multicolumn{2}{|c|}{ Controls, no endotoxin } & - & - & - & - & - & - & - \\
\hline
\end{tabular}

* The agglutination titer of this antiserum with $S$. typhosa strain 0901 was 1:1,000.

added to an equal volume of antiserum, in various dilutions, in standard serological test tubes; incubation was at $52 \mathrm{C}$ for $18 \mathrm{hr}$. Agglutination was read macroscopically; the highest dilution in which clearly visible agglutination occurred was recorded as the serum titer.

Bactericidal test. Tests were conducted in plastic trays containing molded-cup depressions (Disposo-Trays, Linbro Company, New Haven, Conn.). The effect of normal or immune serum on viability was determined by adding an inoculum of 200 bacteria to the desired serum dilution, followed by incubation for $1 \mathrm{hr}$ at $37 \mathrm{C}$; the reaction was terminated by addition of melted agar to the suspensions. After incubation for $18 \mathrm{hr}$ at $37 \mathrm{C}$, colony counts were made and the serum bactericidal effect was determined.

Assay of endotoxin by induction of hemorrhagic necrosis in mouse tumors. $\mathrm{CAF}_{1}$ mice, bearing Sarcoma 37 implanted in the thigh 6 days earlier, were injected intraperitoneally with endotoxin or with gram-negative bacteria. The following day the animals were killed and the tumors examined for induced hemorrhagic necrosis. The extent of tumor damage (Shear, Perrault, and Adams, 1943) induced by the test material was scored in comparison with that of a standard dose of a reference endotoxin.

Inhibition of conditioned hemagglutination by endotoxin. Human $\mathrm{Rh}$ negative type $\mathrm{O}$ erythrocytes were employed, to eliminate the need to adsorb blood group antibodies. They were sensitized with heat-treated Salmonella typhosa endotoxin in the following manner: Cells were washed three times in 10 volumes of saline and made up to a $10 \%$ suspension. Portions of the suspension were mixed with equal volumes of an endotoxin solution containing $1 \mathrm{mg}$ per $\mathrm{ml}$, and incubated for $1 \mathrm{hr}$ at $37 \mathrm{C}$. The cells were then washed with saline three times and diluted to a concentration of $1 \%$. Doubling dilutions of endotoxin in saline were mixed with fresh serum and incubated for $30 \mathrm{~min}$ at $37 \mathrm{C}$. Equal volumes of this mixture and coated red cells were then incubated at $37 \mathrm{C}$ for $1 \mathrm{hr}$ and agglutination was read macroscopically.

\section{RESULTS}

Modification of endotoxin by heat or alkali. It is known that treatment with $0.02 \mathrm{~N} \mathrm{NaOH}$, or heating, is generally required for the fixation of endotoxin on erythrocytes. Accordingly, experiments were performed to determine whether such treatment was also essential for fixation of these complexes on viable bacteria. $E$. coli was grown for $18 \mathrm{hr}$ at $37 \mathrm{C}$ in tryptose broth with $S$. typhosa endotoxin, $1 \mathrm{mg}$ per $\mathrm{ml}$, added to the medium. Endotoxin had first been treated with $0.02 \mathrm{~N} \mathrm{NaOH}$ or by heating at $100 \mathrm{C}$, or was added untreated. Afterward, the cells were centrifuged and washed three times with saline to remove unattached endotoxin, then resuspended and set up in agglutination tests (18 hr at $52 \mathrm{C}$ ) with dilutions of $S$. typhosa antiserum. The results (Table 1) show that endotoxin modified by heating or alkali was more effective in coating $E$. coli, as evidenced by a considerable increase in the serological reactivity of cells exposed to these products. Similar results were obtained with $S$. dysenteriae coated with these preparations.

Duration of interaction between endotoxin and 
bacteria. The time of interaction of cells and endotoxin largely determined the amount of endotoxin taken up by the cells. $E$. coli and S. dysenteriae cultures were incubated at $37 \mathrm{C}$ in tryptose broth containing $1 \mathrm{mg}$ endotoxin per $\mathrm{ml}$ of medium, and samples were removed at intervals varying from $1 / 2$ to $18 \mathrm{hr}$. The bacteria were then washed and resuspended, as previously described, and the uptake of endotoxin was assessed by serological reactivity. From the data for $E$. coli (Table 2), it is evident that the serological activity of the cells with typhoid antibody increased progressively with the time of exposure to endotoxin.

Effect of incubation temperature on uptake of endotoxin. The temperature at which the interaction proceeded also influenced the effectiveness of the fixation process. Shigella and Escherichia strains were incubated overnight with heattreated typhoid endotoxin at 9, 17, and $37 \mathrm{C}$. The washed, resuspended bacteria were set up in agglutination tests with typhoid antiserum. The results for $E$. coli are summarized in Table 3 , which shows that the cells incubated with endotoxin at $37 \mathrm{C}$ were agglutinated to higher titer, i.e., uptake of endotoxin was more effective at this temperature.

Effect of endotoxin concentration. Heat-treated typhoid endotoxin was added to tryptose broth in amounts ranging from 0.1 to $5 \mathrm{mg}$ per $\mathrm{ml}$ of medium to determine the concentration required to render $E$. coli agglutinable by typhoid anti-

TABLE 2. Adsorption of typhoid somatic antigen on viable Escherichia coli; effect of interaction time on uptake of endotoxin

\begin{tabular}{|c|c|c|c|c|c|c|c|}
\hline \multirow{3}{*}{$\begin{array}{c}\text { Time of interaction } \\
\text { between } E \text {. coli and } \\
\text { typhoid endotoxin } \\
\text { (at } 37 \text { C) }\end{array}$} & \multicolumn{7}{|c|}{$\begin{array}{l}\text { Serological reactivity of endotoxin- } \\
\text { treated } E \text {. coli }\end{array}$} \\
\hline & \multicolumn{7}{|c|}{$\begin{array}{l}\text { Agglutination titers (reciprocals) with } \\
\text { Salmonella typhosa antiserum }\end{array}$} \\
\hline & 10 & 20 & 40 & 80 & 160 & 320 & 640 \\
\hline$h r$ & & & & & & & \\
\hline $1 / 2$ & + & + & - & - & - & - & - \\
\hline 1 & + & + & + & - & - & - & - \\
\hline 2 & + & + & + & - & - & - & - \\
\hline 4 & + & + & + & + & - & - & - \\
\hline 8 & + & + & + & + & + & - & - \\
\hline 18 & + & + & + & + & + & + & - \\
\hline $\begin{array}{c}\text { Controls, no } \\
\text { endotoxin. }\end{array}$ & - & - & - & - & - & - & - \\
\hline
\end{tabular}

TABLE 3. Adsorption of typhoid somatic antigen on viable Escherichia coli; effect of incubation temperature on uptake of endotoxin

\begin{tabular}{|c|c|c|c|c|c|c|c|}
\hline \multirow{3}{*}{$\begin{array}{l}\text { Interaction* temp } \\
\text { for } E \text {. coli and } \\
\text { typhoid endotoxin }\end{array}$} & \multicolumn{7}{|c|}{$\begin{array}{l}\text { Serological reactivity of endotoxin-treated } \\
E \text {. coli }\end{array}$} \\
\hline & \multicolumn{7}{|c|}{$\begin{array}{l}\text { Agglutination titers (reciprocals) with } \\
\text { Salmonella typhosa antiserum }\end{array}$} \\
\hline & 10 & 20 & 40 & 80 & 160 & 320 & 640 \\
\hline$C$ & & & & & & & \\
\hline 4 & + & - & - & - & - & - & - \\
\hline 17 & + & + & + & + & - & - & - \\
\hline 37 & + & + & + & + & + & + & - \\
\hline $\begin{array}{l}\text { Controls, no } \\
\text { endotoxin. }\end{array}$ & - & - & - & - & - & - & - \\
\hline
\end{tabular}

* Incubation was for $18 \mathrm{hr}$.

serum. $E$. coli was grown in these endotoxinbroth mixtures for $18 \mathrm{hr}$ at $37 \mathrm{C}$; the cells were washed, resuspended, and set up in agglutination tests with appropriate dilutions of typhoid antiserum. The results (Table 4 ) show that the newly acquired serological reactivity of the organism was dependent on the concentration of endotoxin in the growth medium, with a minimal requirement of $0.1 \mathrm{mg}$ per $\mathrm{ml}$ of medium.

Physiological state of bacteria. The dependence of the effect on incubation temperature suggested that the physiological state of the culture might influence the uptake of endotoxin. To explore this further $E$. coli was incubated for $6 \mathrm{hr}$ with typhoid endotoxin while in the log phase (4-hr broth culture), or in the stationary state (18-hr plate culture). Following such incubation, the treated cells were washed and resuspended and then set up in agglutination tests with typhoid antiserum. Cells killed by heating at $56 \mathrm{C}$ for 1 $\mathrm{hr}$ were included as controls. The results of one of several experiments (Table 5) shows that cells that had been incubated in the log phase are agglutinated with typhoid antiserum to higher titer than are those from stationary phase.

Utilization of endotoxin for growth. The finding that uptake of endotoxin was greatest by bacteria in the log phase of growth suggested that active incorporation of endotoxin rather than mere surface adsorption, may occur. To test this, $E$. coli was grown in a defined medium in which purified typhoid lipopolysaccharide served either as the sole or supplementary source of carbon. No evidence was obtained that the strain of $E$. 
coli could utilize this endotoxin for growth. However, it may be that in the presence of an appropriate nutrient source, endotoxin is actively metabolized for incorporation into cell wall structures. On the other hand, when the endotoxin was hydrolyzed for $1 \mathrm{hr}$ with $1 \mathrm{~N} \mathrm{HCl}$ at $100 \mathrm{C}$, it proved to be a good energy source for growth of this strain. $E$. coli, grown in a medium containing this hydrolyzate as the sole carbon source, was agglutinated by the typhoid anti. serum. It is known that no significant amount of biologically effective endotoxin survives such hydrolysis with $\mathrm{HCl}$. Accordingly, it was concluded that the principal product of the hydrolysis, viz., the haptenic polysaccharide, was utilized not only for growth but was also incorporated into cell wall, in some manner, so as to retain specific typhoid reactivity. It is conceivable that, in the presence of proper substrates for growth, this may also occur with nonhydrolyzed endotoxin.

TABLE 4. Adsorption of typhoid somatic antigen on viable Escherichia coli; effect of endotoxin concentration on its uptake

\begin{tabular}{|c|c|c|c|c|c|c|c|}
\hline \multirow{3}{*}{$\begin{array}{l}\text { Concn. of typhoid } \\
\text { endotoxin in medium } \\
\text { for grow th of } E \text {. coli }\end{array}$} & \multicolumn{7}{|c|}{$\begin{array}{l}\text { Serological reactivity of endotoxin- } \\
\text { treated } E \text {. coli }\end{array}$} \\
\hline & \multicolumn{7}{|c|}{$\begin{array}{l}\text { Agglutination titers (reciprocals) with } \\
\text { Salmonella typhosa antiserum }\end{array}$} \\
\hline & 10 & 20 & 40 & 80 & $\mid \begin{array}{l}160 \\
\text { | }\end{array}$ & 320 & 640 \\
\hline $\mathrm{mg} / \mathrm{ml}$ & & & & & & & \\
\hline 0.01 & - & - & - & - & - & - & - \\
\hline 0.1 & + & - & - & - & - & - & - \\
\hline 1.0 & + & + & + & + & + & + & - \\
\hline 5.0 & + & + & + & + & + & + & - \\
\hline
\end{tabular}

Quantity of endotoxin attached to cells. Two kinds of experiments were performed to determine the amount of endotoxin which, under optimal conditions, was taken up by the bacteria. The endotoxic potency of cells grown with endotoxin was determined in the tumor damage assay. The results of this experiment (Table 6) indicate that a small but significant amount of endotoxin was attached to the cells. In another experiment the unadsorbed endotoxin remaining in the medium was determined by the hemagglutination inhibition technique. After removal of bacteria by centrifugation, appropriate dilutions of the medium were added to samples of $1: 100$ dilution of $S$. typhosa antiserum. The mixtures were incubated at $37 \mathrm{C}$ for $30 \mathrm{~min}$ and erythrocytes coated with typhoid endotoxin were added. For purpose of comparison, tests were included with typhoid endotoxin, omitting the $E$. coli inoculum. The control (untreated) endotoxin was four times as potent as the centrifuged supernatant with regard to inhibition of the specific hemagglutination. This indicates that approximately $75 \%$ of the added endotoxin had either been taken up by the bacteria or had, in some way, been altered by the cells.

The differences in the results obtained in these two experiments may be a reflection of changes in the endotoxin produced in the course of bacterial growth. The data suggest that, whatever is the nature of the changes, they affect the toxic rather than the serological capabilities of the endotoxin.

Bactericidal action of fresh serum on $E$. coli and S. dysenteriae treated with typhoid endotoxin. The previously determined conditions under

TABLE 5. Adsorption of typhoid somatic antigen on viable Escherichia coli; effect of physiological state of cells on uptake of endotoxin

\begin{tabular}{|c|c|c|c|c|c|c|c|}
\hline \multicolumn{2}{|c|}{ Modification of $E$. coli for agglutination tests } & \multicolumn{6}{|c|}{ Serological reactivity of endotoxin treated $E$. coli } \\
\hline \multirow{2}{*}{ Physiological state } & \multirow{2}{*}{$\begin{array}{l}\text { Interaction of } E . \text { coli } \\
\text { and typhoid endotoxin }\end{array}$} & \multicolumn{6}{|c|}{ Agglutination titers (reciprocals) with Salmonella typhosa antiserum } \\
\hline & & 10 & 20 & 40 & 80 & 160 & 320 \\
\hline Log phase (3-hr growth) & Incubated for $6 \mathrm{hr}$; & + & + & + & + & + & - \\
\hline $\begin{array}{l}\text { Stationary phase (18-hr } \\
\text { growth) }\end{array}$ & $\begin{array}{l}\text { washed } 3 \text { times } \\
\text { with saline }\end{array}$ & + & + & + & - & - & - \\
\hline Heat killed (56 C, $1 \mathrm{hr})$ & & + & + & - & - & - & - \\
\hline \multicolumn{2}{|c|}{ Controls, $E$. coli (log phase growth) ........ } & - & - & - & - & - & - \\
\hline
\end{tabular}


TABLE 6. Adsorption of typhoid somatic antigen on viable Escherichia coli; endotoxic potency of treated bacteria

\begin{tabular}{|c|c|c|c|c|c|}
\hline \multirow{2}{*}{ Treatment of $E$. coli } & \multicolumn{5}{|c|}{$\begin{array}{l}\text { Quantity of } E \text {. coli required to } \\
\text { evoke hemorrhagic necrosis in } \\
\text { Sarcoma } 37 \text { implants in mice }\end{array}$} \\
\hline & $5 \mu \mathrm{g}$ & $10 \mu \mathrm{g}$ & $25 \mu \mathrm{g}$ & $50 \mu \mathrm{g}$ & $75 \mu \mathrm{g}$ \\
\hline $\begin{array}{l}\text { Grown with typhoid } \\
\text { endotoxin* }(1 \mathrm{mg} / \mathrm{ml} \\
\text { medium }) \text { for } 18 \mathrm{hr} \mathrm{at} \\
37 . \mathrm{C}\end{array}$ & $0 / 10$ & $4 / 10$ & $8 / 10 \dagger$ & $10 / 10$ & $10 / 10$ \\
\hline None & $0 / 10$ & $1 / 10$ & $3 / 10$ & $8 / 10$ & $10 / 10$ \\
\hline
\end{tabular}

* The typhoid endotoxin alone had the following tumor-damaging potency: $1 \mu \mathrm{g} /$ mouse, $1 / 10$; $5 \mu \mathrm{g} /$ mouse, $6 / 10 ; 10 \mu \mathrm{g} /$ mouse, $10 / 10$.

$\dagger$ Fractions $=$ (no. mice with damaged tumors) $/$ (no. mice tested).

which endotoxin was taken up by viable bacteria were utilized to explore further the effect of adherent or incorporated endotoxin on the susceptibility to serum of the treated bacteria. Since it had already been determined that the duration of the interaction, between endotoxin and bacteria in the log phase of growth, affected the amount of endotoxin taken up by the bacteria, the following conditions were employed: Four-hour cultures of $E$. coli and S. dysenteriae containing $1 \times 10^{8}$ cells per $\mathrm{ml}$ were incubated with typhoid endotoxin in a concentration of 1 $\mathrm{mg}$ per $\mathrm{ml}$ of medium; samples of the culture were removed for test after 1 and $18 \mathrm{hr}$ of incubation at $37 \mathrm{C}$. The endotoxin-treated bacteria ${ }^{2}$ and corresponding control cultures were washed with saline three times and then set up in tests with serial dilutions of pooled normal human serum. After incubation for $1 \mathrm{hr}$ at $37 \mathrm{C}$, the surviving bacteria were enumerated by plating as described previously. The results of typical experiments are summarized in Tables 7 and 8. It can be seen that $E$. coli and $S$. dysenteriae, grown for $1 \mathrm{hr}$ with typhoid endotoxin, were appreciably more susceptible than were control cells to the bactericidal action of normal serum. In contrast, $E$. coli and $S$. dysenteriae grown for

2 Slide agglutination tests were made with bacteria washed three times and typhoid antiserum. The organisms grown with endotoxin were agglutinated promptly, showing that both $E$. coli and $S$. dysenteriae had indeed taken up the heterologous endotoxin.
TABLE 7. Bactericidal action of normal human serum on Escherichia coli treated with typhoid endotoxin

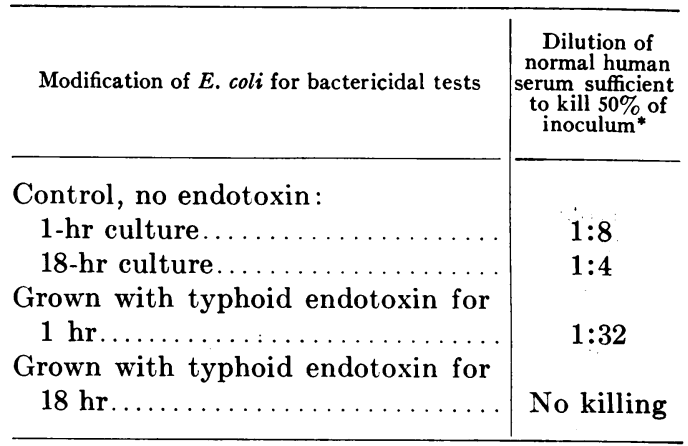

* Inoculum of 200 cells, incubated with serum for $1 \mathrm{hr}$ at $37 \mathrm{C}$.

TABLE 8. Bactericidal action of normal human serum on Shigella dysenteriae treated with typhoid endotoxin

\begin{tabular}{|c|c|}
\hline $\begin{array}{c}\text { Modification of } S . d y \text { senteriae for bactericidal } \\
\text { tests }\end{array}$ & $\begin{array}{l}\text { Dilution of } \\
\text { normal human } \\
\text { serum sufficient } \\
\text { to kill } 50 \% \text { of } \\
\text { inoculum* }\end{array}$ \\
\hline $\begin{array}{l}\text { Control, no endotoxin: } \\
\text { 1-hr culture } \ldots \ldots \ldots \ldots \ldots \ldots \ldots \ldots \ldots \ldots \ldots \ldots \ldots \\
\text { 18-hr culture } \ldots \ldots \ldots \ldots \ldots \ldots\end{array}$ & $\begin{array}{l}1: 4 \\
1: 2\end{array}$ \\
\hline 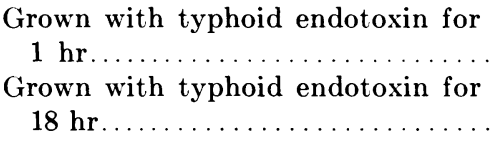 & $\begin{array}{l}1: 24 \\
\text { No killing }\end{array}$ \\
\hline
\end{tabular}

* Inoculum of 200 cells, incubated with serum for $1 \mathrm{hr}$ at $37 \mathrm{C}$.

$18 \mathrm{hr}$ in the presence of the typhoid somatic antigen proved to be markedly resistant to the potential bactericidal effects of the very same serum.

To further define the means by which endotoxin taken up by microorganisms altered the bactericidal effect of normal serum on the cells, the following experiments were performed: $E$. coli, coated with typhoid endotoxin as described, and control cells, were incubated for $1 \mathrm{hr}$ at $37 \mathrm{C}$ with antiserum to $E$. coli or S. typhosa and complement (normal human serum which had been adsorbed at $4 \mathrm{C}$ with the homologous test strain). The results of this experiment, given in abridged form in Table 9, show that, as expected, the lethal effect of immune antibody and complement was exerted only in those situations 
TABLE 9. Bactericidal action of immune serum on Escherichia coli treated with typhoid endotoxin

\begin{tabular}{|c|c|c|c|c|}
\hline \multirow{3}{*}{ Modification of $E$. coli for bactericidal tests } & \multicolumn{4}{|c|}{ Bactericidal action of human complement* and specific antibody $\dagger$} \\
\hline & $\begin{array}{c}\text { Control (no } \\
\text { antibody) }\end{array}$ & $\begin{array}{l}\text { Typhoid } \\
\text { antibody }\end{array}$ & $\begin{array}{c}\text { Coli } \\
\text { antibody }\end{array}$ & $\begin{array}{c}\text { Typhoid } \\
+ \text { coli } \\
\text { antibodies }\end{array}$ \\
\hline & \multicolumn{4}{|c|}{ Serum dilution sufficient to kill $50 \%$ of inoculum $\ddagger$} \\
\hline \multicolumn{5}{|l|}{ Controls, no endotoxin: } \\
\hline 1-hr culture.... & No killing & No killing & $1: 16$ & $1: 16$ \\
\hline 18-hr culture... & No killing & No killing & $1: 10$ & $1: 10$ \\
\hline Grown with typhoid endotoxin for $1 \mathrm{hr}$. & No killing & $1: 64$ & $1: 16$ & $1: 64$ \\
\hline Grown with typhoid endotoxin for $18 \mathrm{hr}$. & No killing & $1: 4$ & $1: 4$ & $1: 2$ \\
\hline
\end{tabular}

* Normal human serum adsorbed with $E$. coli strain 47.

$\dagger$ Rabbit antiserum to Salmonella typhosa strain 0901 and to $E$. coli strain 47 . These sera were used in a dilution of $1: 1,000$.

‡ Inoculum of 200 cells, incubated with serum for $1 \mathrm{hr}$ at $37 \mathrm{C}$.

where test organisms and antibody were homologous. But after exposure to typhoid endotoxin for $1 \mathrm{hr}$ the coli cells were readily killed by either typhoid or coli antiserum plus complement. It is noteworthy that typhoid antiserum led to killing of these coated cells in higher dilutions than the coli antiserum. In conformity with the previous findings with normal serum, cells exposed to typhoid endotoxin for $18 \mathrm{hr}$ were significantly less responsive to the bactericidal effect of complement and immune serum.

\section{DISCUSSION}

In the present work the bactericidal effects of serum on two gram-negative species were modified by exposing these bacteria to endotoxin of heterologous origin. In this manner further evidence was obtained in support of previous findings (Michael and Landy, 1961) that the amount of endotoxin present in these organisms influences the bactericidal reaction.

The adsorption of endotoxins, and other complex polysaccharides, on the surface of various types of cells has been the subject of extensive studies. In most of the investigations the cell employed has been the mammalian erythrocyte. The nature of this attachment has remained obscure, and little is known about the mechanism by which endotoxin can modify cellular properties so that after cells are exposed to antibody and complement a complex series of reactions ensues leading to cell destruction. Indirect evidence of the adsorption of endotoxin on bacteria is found in a report by Billaudelle (1949) who employed autoclaved medium in which gram-negative species had been grown and subsequently reinoculated with an unrelated enteric species; the latter strains acquired the antigenic properties of the former species, as shown by agglutination with specific antibody. His observations may now be interpreted as representing a "coating" effect with endotoxin which had been extracted into the growth medium by autoclaving of the original culture. Subsequently Adler (1952) reported that the bactericidal reaction could be mediated by antibodies directed against a heterologous lipopolysaccharide adsorbed on the bacterial surface.

In the course of the present study these observations have been confirmed and the conditions required for uptake of endotoxin by viable cells have been explored. It was found that the modifcation of the cells is dependent upon the duration of exposure to endotoxin, its concentration, and the interaction temperature. Perhaps the most interesting but least understood observation relates to the effect of the physiological state of the bacteria on the extent of adsorption of endotoxin. Bacteria in the log phase of growth took up more endotoxin from the medium and were more effectively coated than cells in the stationary phase of growth. It was at first believed that this was associated with a utilization of endotoxin, since in the phase of rapid growth and metabolism the endotoxin would be taken up more effectively. However, we were unable to demonstrate utilization of endotoxin by the test strains when this complex was provided as 
the sole carbon source. This does not preclude the possibility that in a nutrient medium, endotoxin is to some extent actually utilized by the bacteria. Thus bacterial alteration by endotoxin may involve considerably more than mere adsorption and it is possible that the greater effectiveness of incubation with endotoxin during the log phase actually reflects a metabolic conversion of extracellular endotoxin into surface material. It remains for future work to determine which of these alternatives is applicable to the modification of viable gram-negative organisms by endotoxin.

There are many factors which affect the outcome of the interaction between fresh serum and gram-negative bacteria. It is well known, for example, that the physiological state (age of the culture) influences profoundly the bactericidal reaction (Michael and Braun, 1959). The mechanism by which adsorption or incorporation of endotoxin on or into bacteria leads to altered susceptibility to the bactericidal effect of serum is of course even more difficult to approach experimentally. The complexity of the change is illustrated by the finding that, depending on the conditions of exposure of the bacteria to endotoxin, the effect of serum could be either augmented or diminished to a considerable extent. This appeared to be related to the concentration of endotoxin to which the cells were exposed. The finding that coated cells were susceptible to antibody directed against the adsorbed antigen shows that the increased susceptibility involved the new immunological specificity conferred on the cell. However, the added antigen does not blanket entirely the native somatic antigens of the bacteria, as was shown in agglutination tests in which the original serological reactivity of the cells was still retained. Furthermore, the bactericidal reaction could still be initiated by employing immune antibody directed against the native somatic antigen; normal serum brought about similar bactericidal effects on these "coated" cells. It is noteworthy, however, that combination of antibodies against both the bacterium and the adsorbed antigen failed to enhance susceptibility to serum.

It seems rather unlikely that endotoxin, taken up by bacteria under appropriate conditions of time and temperature, would occupy a position on the bacterial surface comparable to that of endotoxin synthesized by the cell and oriented on its surface. Heterologous somatic antigen thus artificially attached to the cell may be visualized as being a good deal less firmly integrated with the cell surface than antigen synthesized by the cell and consequently an integral part of the cell wall. It is nonetheless evident that antigens taken up in this manner do effectively complete the process leading to cell destruction.

The exposure of cells to endotoxin for longer intervals resulted in decrease of their susceptibility to serum. Since the adsorption was found to be time dependent it was initially assumed that exposure for longer periods of time resulted in the uptake of more endotoxin. In bactericidal tests with those cells, increase of antibody concentration in the reaction inixture, contrary to expectation, had little or no additional effect on the outcome. Thus the assumption that the reaction was affected by an unfavorable ratio between antigen and antibody concentrations appeared unlikely.

There is no doubt that the amount of antibody required to initiate the bactericidal serum reaction is rather small. The amount of lipopolysaccharide taken up by the bacteria was also small as disclosed in tests of the endotoxic reactivity of the treated cells and in assays of the amount of endotoxin remaining in the medium after the cells had been removed. Although the amounts of endotoxin taken up by the bacteria were relatively minute, they sufficed nonetheless to cause major changes in bacterial reactivity. Present indications are that the quantities of endotoxin involved in these effects do not differ appreciably from those which confer a new serological specificity on the cell.

\section{ACKNOWLEDGMENT}

The authors wish to express their thanks to Philip W. Stashak for capable technical assistance and to Werner Braun and Murray $\mathrm{J}$. Shear for helpful suggestions in the preparation of this report.

\section{LITERATURE CITED}

Adler, F. L. 1952. Bactericidal action mediated by antibodies specific for heterologous antigens adsorbed to bacterial cells. Proc. Soc. Exptl. Biol. Med. 79:590-593.

Billaudelle, H. 1949. Experimentelle Erwerbung neuer serologischer Eigenschaften von Bakterien durch Züchtung in heterologen Kulturfiltraten. Z. Immunitätsforsch. 106:7788. 
Davies, D. A. L., M. J. Crumpton, I. A. Michael, J. G., and M. Landy. 1961. Endotoxic Macpherson, and A. M. Hutchison. 1958. The absorption of bacterial polysaccharides by erythrocytes. Immunology 1:157-171.

De Gregorio, M. 1955. Fissazione di antigeni sulla superficie cellulare. Boll. ist. sieroterap. milan. 34:118-122.

Michael, J. G., and W. Braun. 1959. Modification of bactericidal effects of human sera. Proc. Soc. Exptl. Biol. Med. 102:486-490. properties of gram-negative bacteria and their susceptibility to the lethal effect of normal serum. J. Infectious Diseases. 108:9094.

Shear, M. J., A. Perrault, and J. R. Adams. 1943. Chemical treatment of tumors. VI. Method employed in determining the potency of hemorihage-producing bacterial preparations. J. Natl. Cancer Inst. 4:99-105. 